\title{
Lack of detection of human papillomavirus DNA in male urine samples
}

\author{
P M Geddy, M Wells, C J N Lacey
}

\begin{abstract}
Objectives-To evaluate polymerase chain reaction (PCR) methodology for the detection of urethral human papillomavirus (HPV) infection by examining urinary sediment from males.

Setting-Department of Genitourinary Medicine, Leeds General Infirmary.

Subjects-73 male patients attending for treatment of sexually transmitted diseases, including 14 patients with genital warts which did not involve the urethral meatus.

Methods-Urinary sediment was tested for HPV DNA and human beta globin gene DNA by PCR methodology. A consensus primer set capable of detecting a wide range of HPV types was used. PCR product was analysed by gel electrophoresis and ethidium bromide staining. Results-HPV DNA was not detected in any of the specimens. Human beta globin gene DNA was identified in 40 of the 73 specimens $(55 \%)$.

Conclusions-Screening urinary sediment for HPV DNA by PCR methodology with analysis of PCR product by gel electrophoresis and ethidium bromide staining is probably unhelpful for studying the prevalence of urethral HPV infection in men.
\end{abstract}

(Genitourin Med 1993;69:276-279)

\section{Introduction}

Human papillomavirus (HPV) is intimately involved in the pathogenesis of anogenital neoplasia. A close association between HPV in most cases of invasive cervical cancer has now been established. ${ }^{2}$ Genital HPV infection is sexually transmitted amongst young adults and its epidemiology in women is well described. ${ }^{3}$ However, less is understood concerning the epidemiology of genital HPV in men and the precise mechanism of sexual transmission. The relatively frequent occurrence of subclinical lesions of the glans and prepuce of the penis was initially demonstrated by colposcopy ${ }^{4} 5$ and subsequently by HPV DNA detection. ${ }^{6}$ Condylomata acuminata occurring within the urethral meatus, and rarely more proximally within the urethra are well described. However, the possibility of a urethral location for subclinical genital HPV infection was initially suggested by urinary cytology ${ }^{4}$ and more recently by Southern blot detection of HPV DNA using urethral brush- ings in men with a normal urethroscopy.

The use of urine samples to detect HPV DNA was first reported in men with intrameatal warts where types 6 and 11 were detected. ${ }^{8}$ Another recent study reported the presence of HPV 16 in urine in three out of 22 males. ${ }^{9}$ Urine is simple to collect and could provide a convenient noninvasive specimen for screening large male populations for urethral HPV infection. We decided to evaluate the use of polymerase chain reaction (PCR) methodology, with a consensus primer set detecting a broad range of HPV types, on urine samples from males attending a sexually transmitted disease clinic.

\section{Method}

First voided urine specimens were collected in sterile plastic containers from 73 male patients attending the Department of Genitourinary Medicine at Leeds General Infirmary. Genital warts were present in $14(19 \%)$ patients although none of these men had intrameatal lesions. Urethroscopy was not performed. The specimens were $20 \mathrm{ml}$ in volume and were stored at $4^{\circ} \mathrm{C}$ for up to 4 hours.

The urine was centrifuged for 10 minutes at $500 \mathrm{~g}$ and the supernatant was discarded. The sediment was rinsed twice in $10 \mathrm{ml}$ of phosphate buffered saline, resuspended in $1 \mathrm{ml}$ of phosphate buffered saline and transferred to a $1.5 \mathrm{ml}$ microfuge tube. The sediment was pelleted by centrifugation, resuspended in $30 \mu \mathrm{l}$ of digestion buffer $(100$ $\mathrm{mM} \mathrm{NaCl}, 10 \mathrm{mM}$ Tris- $\mathrm{HCl}, 25 \mathrm{mM}$ EDTA, $0.5 \%$ SDS, $\mathrm{pH} 8.3$ ) with $0.1 \mathrm{mg} / \mathrm{ml}$ of proteinase $\mathrm{K}$ (Sigma) and incubated at $37^{\circ} \mathrm{C}$ overnight. DNA was extracted twice with an equal volume of phenol/ chloroform/iso-amyl alcohol (25:24:1) and once with an equal volume of chloroform/isoamyl alcohol (24:1). DNA was precipitated at $-20^{\circ} \mathrm{C}$ with one tenth volume $3 \mathrm{M}$ sodium acetate and two volumes of cold ethanol, pelleted by centrifugation, dried under vacuum and redissolved in $30 \mu \mathrm{l}$ of sterile water. The concentration of extracted DNA was measured by a DNA minifluorometer (Model TKO 100, Hoefer Scientific Instruments) which measures the fluorescence of Hoescht 33258 (Polysciences) in the presence of DNA. Human placental DNA (Clontech Laboratories) at $100 \mathrm{ng} / \mu \mathrm{l}$ was used to calibrate the minifluorometer.

The extracted DNA was tested for HPV DNA and human beta globin gene DNA by 
DNA sequences of oligonucleotide primers

$\begin{array}{ll}\text { HPV L1 (-) } & \text { 5'-CGTCC(AC)A(AG)(AG)CGA(AT)ACTGATG-3' } \\ \text { HPV L1 (+) } & \text { 5'-GC(AC)CAGGG(AT)CATAA(CT)AATCG-3' } \\ \text { BETA GLOBIN (-) } & \text { 5'-CAACTTCATCCACGTTCACC-3' } \\ \text { BETA GLOBIN (+) } & \text { 5'-ACACAACTGTGTTCACTAGA-3' }\end{array}$

PCR methodology in separate assays. A consensus primer set was used to detect HPV DNA which was highly homologous to the L1 open reading frame DNA sequence of a large number of HPV types. The oligonucleotide primers (table) were synthesised on a DNA synthesiser (Applied Biosystems 391).

All amplification reactions were carried out in a total volume of $50 \mu \mathrm{l}$ and the reaction mixture comprised $50 \mathrm{mM} \mathrm{KCl}, 10 \mathrm{mM}$ TRIS-HCl (pH 8.3), $1.5 \mathrm{mM} \mathrm{MgCl}, 0.01 \%$ gelatin, $0.2 \mathrm{mM}$ each of dATP, dCTP, dGTP and dTTP, 50 picomoles of each oligonucleotide primer and 1 unit of thermostable Super Taq DNA polymerase (HT Biotechnology). Extracted DNA (200 ng) for the HPV assay and 100ng of extracted DNA for the beta globin assay were added to the reaction mixture. If DNA was not detected by DNA fluorimetry, $10 \mu \mathrm{l}$ of the digests were added to the reaction mixture and the total volume was maintained at $50 \mu \mathrm{l}$. The reaction mixtures were overlayed with $50 \mu 1$ of mineral oil to prevent evaporation. Positive and negative DNA controls were included with each batch of specimens. The positive control for the HPV assay was 10ng of HPV 16 plasmid DNA and for the beta globin assay was $10 \mathrm{ng}$ of purified human placental DNA.

The specimens underwent 40 cycles of amplification using a programmable thermal controller (MJ research programmable thermal controller, Genetic Research Instrumentation). For the HPV assay, an initial cycle of denaturation at $94^{\circ} \mathrm{C}$ for 5 minutes, annealing at $50^{\circ} \mathrm{C}$ for 1.5 minutes and primer extension at $72^{\circ} \mathrm{C}$ for 2 minutes was followed by 39 cycles at $94^{\circ} \mathrm{C}$ for 30 seconds, $50^{\circ} \mathrm{C}$ for 1.5 minutes and $72^{\circ} \mathrm{C}$ for 2 minutes with a final extension at $72^{\circ} \mathrm{C}$ for 5 minutes. For the beta globin assay an initial cycle of denaturation at $94^{\circ} \mathrm{C}$ for 5 minutes, annealing at $50^{\circ} \mathrm{C}$ for 1 minute and primer extension at $72^{\circ} \mathrm{C}$ for 2 minutes was followed by 39 cycles at $94^{\circ} \mathrm{C}$ for 1 minute, $50^{\circ} \mathrm{C}$ for 1 minute and $72^{\circ} \mathrm{C}$ for 2 minutes with a final extension at $72^{\circ} \mathrm{C}$ for 5 minutes. PCR product underwent electrophoresis and was run in a $2 \%$ agarose gel (Sigma) for 90 minutes at 150 volts. A 123 basepair ladder (BRL) was used as a standard. After electrophoresis, the gel was stained with ethidium bromide, examined by ultraviolet light fluorescence and photographed.

To reduce the risks of contamination, preparation of reagents, DNA extraction, DNA amplification and DNA identification were performed in different rooms. The positive DNA controls and extracted DNA were added to their PCR reaction mixtures in separate rooms. Other precautions included using disposable gloves, dedicated positive displacement pipettes, disposable sterile pipette tips, sterile tubes, and dedicated microfuges and other equipment. Sterile water was used as a reagent contamination control and was processed alongside each batch of specimens.

\section{Results}

HPV DNA was not detected in any of the specimens. Human beta globin gene DNA was identified in 40 of the 73 samples (55\%).

\section{Discussion}

Only the distal $1-2 \mathrm{~cm}$ of the male urethra is lined by stratified squamous epithelium. The penile, bulbar and prostatic urethrae are lined by pseudostratified columnar epithelium, although this may undergo squamous metaplasia, especially after severe infection or inflammation. HPV appears to be adapted to infect productively squamous epithelium although the possibility of infection of columnar epithelium (as in the endocervix) cannot be ruled out. A recent prospective study examined men who had meatal lesions within the distal $15 \mathrm{~mm}$ of the urethra by urethroscopy and showed only $8 \%$ to have more proximal lesions (Aynaud and Barrasso-personal communication). A retrospective surgical pathology review of urethral condylomata showed that $80 \%$ of lesions occurred within the terminal $3 \mathrm{~cm}$ and that involvement of the prostatic and bulbar urethrae was always accompanied by involvement of the penile urethra. ${ }^{10}$ The frequency of involvement of the terminal urethra in men with external condylomata when speculum examination of the terminal urethra was performed routinely was $9 / 56(16 \%){ }^{11}$

A number of studies have provided some evidence for subclinical HPV infection of the distal urethra when direct collection of cells from this site is performed. Rosemberg et al examined 122 men who were sexual partners of women with CIN and genital warts. ${ }^{11}$ Inspection of the distal urethra by speculum was performed and in men without macroscopic lesions, three of $113(2 \cdot 7 \%)$ were positive by Virapap (two type $6 / 11$, one type 16/18). Kataoka et al studied unselected army conscripts and examined the external penile epithelium by colposcopy and biopsy, and collected distal urethral cells by brushing. In men with normal external penile epithelium $4 / 66(6 \%)$ and $8 / 66(12 \%)$ showed urethrae positive for HPV DNA (types 6, 11, and 33), by Southern blot and PCR respectively. ${ }^{12}$ Van Doornum et al examined a population of highly promiscuous heterosexual males and found 11/65 (17\%) (1 type 6/11, 3 type 16, 7 type 18) HPV DNA positive on urethral swab by PCR. ${ }^{13} \mathrm{~A}$ study in Paris has examined 110 male partners of women with CIN by colposcopy, meatoscopy, urethroscopy and collection of urethral scrapings (Aynaud, Gorgette and Barrasso-personal communication). HPV DNA was determined by 
Southern blot and PCR and detected in $15 / 21(71 \%)$ of men with urethral lesions, $5 / 34(21 \%)$ of men with only penile lesions, $1 / 34(2.9 \%)$ of men with no evidence of urethral lesions, and $1 / 21(4 \cdot 8 \%)$ of men previously treated for urethral lesions.

One of the two previously published studies which examined male urine samples for HPV DNA compared men with meatal warts, with laboratory workers as controls, showing 15/17 (types $6 \& 11$ ) and $0 / 15$ positives respectively. ${ }^{8}$ Nakazawa et al also used PCR methodology and found HPV 16 DNA in two out of eight male consorts of HPV 16 positive women and one out of fourteen male consorts of HPV 16 and HPV 18 negative women. ${ }^{9}$

We did not detect HPV DNA in urinary sediment from 73 men attending a genitourinary clinic using PCR methodology with consensus primers to the $\mathrm{Ll}$ open reading frame. Human beta globin gene DNA was successfully amplified in $55 \%$ of the specimens indicating the presence of human genomic DNA. Apart from the absence of human genomic DNA in the remaining specimens, possible reasons for not detecting DNA include a failure to extract small amounts of DNA from the urinary sediment and the presence of PCR inhibitors. However, rinsing the sediment in phosphate buffered saline would have largely removed soluble urinary PCR inhibitors such as urea. ${ }^{14}$

Genital warts were found in $14(19 \%)$ of our patients by routine clinical examination. There was no meatal involvement but endoscopic examination of the urethra was not performed. Urethral HPV infection may not have been present in any of our patients, accounting for the absence of HPV DNA in their urinary sediment. Another possibility is that although a minority of our patients may have had urethral HPV infection, HPV infected cells may not have been shed into their urine. This may occur as studies of male sexual partners of women with genital HPV infection have shown that screening urine for cytological features of HPV infection is ineffective. ${ }^{415}$ In contrast, a study of a similar cohort using urethral brushings rather than urine, found cytological evidence of HPV infection in $43 \%$ of cases. ${ }^{16}$ However, a lack of HPV infected cells in the urine may only be seen with non-condylomatous lesions as Melchers et al detected HPV DNA in the urinary sediment of most of their patients with meatal condylomata acuminata. ${ }^{8}$ The male subjects in the report by Nakazawa et al showed no clinical evidence of HPV infection, but it is not stated whether the urethra was examined. ${ }^{9}$ Furthermore, the few urine specimens with cytological features of HPV infection in the previously mentioned studies were mostly associated with urethral condylomata acuminata. ${ }^{415}$

There were a number of differences in the methodology between this report and the previous studies of urinary sediment which may account for the difference in results. ${ }^{89}$ The latter collected larger volumes of urine from each subject and possibly larger amounts of
DNA, but PCR methodology is extremely sensitive and can detect very small amounts of DNA. The previous studies used type specific HPV primer sets rather than a general HPV primer set, but a large range of HPV types can be detected by general primer sets. ${ }^{17} \mathrm{~A}$ more significant difference is that the previous studies used the more sensitive technique of Southern blot hybridisation with oligonucleotide probes to assess PCR product rather than gel electrophoresis followed by ethidium bromide staining. This increases sensitivity of HPV detection by 100 -fold. ${ }^{18}$ Nakazawa et al also used early morning urine samples and microscopy to confirm the presence of epithelial cells in their specimens ${ }^{9}$ whereas amplification of human beta globin gene DNA by PCR methodology was used in this study to confirm the presence of human genomic DNA and its extraction from the specimens. Melchers et al did not establish whether their specimens contained epithelial cells or human genomic DNA, and some of their specimens in which they did not detect HPV DNA may have been false negatives. ${ }^{8}$

In conclusion, screening urinary sediment for HPV DNA by PCR methodology with analysis of PCR product by gel electrophoresis and ethidium bromide is probably unhelpful for studying the prevalence of genital HPV infection in men.

We thank Gerald Booth, Department of Genitourinary Medicine, Leeds General Infirmary; the staff of the Department of Biosciences, Academic Unit of Pathology, University of Leeds; and Jenny Southgate, Institute of Cancer Studies, St James's University Hospital, Leeds.

1 Munoz N, Bosch FX. HPV and cervical neoplasia: review of case-control and cohort studies. In: Munoz N, Bosch FX, Shah KV, Meheus A. The Epidemiology of Cervical Cancer and Human Papillomavirus. 1992, pp 251-261. Lyon, International Agency for Research on Cancer.

2 Riou G, Favre M, Jeannel D, Bourhis J, Le Doussal V, Orth G. Association between poor prognosis in earlyOrth $\mathrm{G}$. Asiociation betwer por prosnosis in earlyDNA. Lancet 1990;335:1171-4.

3 Schiffman MH. Recent progress in defining the epidemiology of human papillomavirus infection and cervical neoplasia. 7 Natl Cancer Inst 1992;84:394-8.

4 Levine RU, Crum CP, Herman E, Silvers D, Ferenczy A, Richart RM. Cervical papillomavirus infection and intraepithelial neoplasia: a study of male sexual partners. Obstet Gynecol 1984;64:16-20.

5 Rosemberg SK. Subclinical papilloma viral infection of male genitalia. Urology 1985;26:554-7

6 Grussendorf-Conen E-I, de Villiers E-M, Gissmann L. Human papillomavirus genomes in penile smears of healthy men. Lancet 1986;i: 1092 .

7 Rosemberg SK, Reid R, Greenberg M, Lorincz AT. Sexually transmitted papillomaviral infection in the
male: II. The urethral reservoir. Urology 1988;32:47-9.

8 Melchers WJG, Schift R, Stolz E, Lindeman J, Quint WGV. Human papillomavirus detection in urine samples from male patients by the polymerase chain reacples from male patients by the polym
tion. $₹$ Clin Microbiol $1989 ; 27: 1711-4$.

9 Nakazawa A, Inoue M, Fujita M, Tanizawa O, Hakura A Detection of human papillomavirus type 16 in sexual partners of patients having cervical cancer by polymerase chain reaction. $\mathcal{F p}_{p n} \mathcal{f}$ Cancer Res 1991;82: $1187-90$.

10 Morrow RP, McDonald JR, Emmett JL. Condylomata acuminata of the urethra. $₹$ Urol 1952;68:909-17.

11 Rosemberg SK, Husain M, Herman GE, Elfont EA. Sexually transmitted papillomaviral infection in the male: VI. simultaneous urethral cytology -Virapap the male: papillomaviral infection. Urology 1990;36:38-41.

12 Kataoka A, Claesson U, Hansson BG, Eriksson M, Lindh E. Human papillomavirus infection of the male diagnosed by Southern-blot hybridisation and polymerase chain reaction: comparison between urethra samples and penile biops samples. 13 van Doornum GJJ, Hooykaas C, Juffermans LHJ, et al. Prevalence of human papillomavirus infections among 
heterosexual men and women with multiple sexual partners. F Med Virol 1992;37:13-21.

14 Khan G, Kangro HO, Coates PJ, Heath RB. Inhibitory effects of urine on the polymerase chain reaction for cytomegalovirus DNA. $f$ Clin Pathol 1991;44:360-5.

15 Kennedy L, Buntine DW, O'Connor D, Frazer IH Human papillomavirus-a study of male sexual partners. Med $\tilde{f}$ Aust 1988;149:309-11.

16 Cecchini S, Cipparrone I, Confortini M, Scuderi A, Meini L Piazzesi G. Urethral cytology of cytobrush specimens: a new technique for detecting subclinical human papillomavirus infection in men. Acta Cytol 1988; 32:314-17

17 van den Brule AJC, Meijer CILM, Bakels V, Kenemans $P$, Walboomers JMM. Rapid detection of human papillomavirus in cervical scrapes by combined general primer-mediated and type-specific polymerase chain reaction. f Clin Microbiol 1990;28:2739-43.

18 Morrison EAB, Goldberg GL, Kadish AS, Burk RD Polymerase chain reaction detection of human papillomavirus: quantitation may improve clinical utility. $\mathcal{f}$ Clin Microbiol 1992;30:2539-43. 